\title{
Efektivitas Pemungutan Pajak Hotel Dan Restoran Di Kabupaten Manokwari Provinsi Papua Barat
}

\author{
Johanes Paulus Koromath ${ }^{1}$ \\ ${ }^{1}$ Dosen Jurusan Ekonomi Pembangunan, Universitas Papua
}

Received: Juni 2019; Accepted: Agustus 2019; Published: September 2019

\begin{abstract}
Abstrak
Penelitian ini bertujuan untuk mengetahui efektivitas pemungutan pajak hotel dan restoran dan kontribusinya terhadap Pendapatan Asli Daerah selama periode tahun 2014 sampai 2018. Metode pengumpulan data dalam penelitian ini adalah observasi non partisipan. Variabel dalam penelitian ini adalah rasio efektivitas dan kontribusi. Teknik analisis data pada penelitian ini adalah analisis kuantitatif. Berdasarkan hasil analisis, ratarata efektivitas pemungutan pajak hotel dan restoran di Kabupaten Manokwari adalah 91 persen dengan kategori efektif dan rata-rata kontribusi pemungutan pajak hotel dan restoran pada Pendapatan Asli Daerah Kabupaten Manokwari tahun 2014 - 2018 sebesar 10,82, dimana termasuk pada kategori kurang baik.
\end{abstract}

Kata kunci: efektivitas, kontribusi, pajak hotel dan restoran, PAD

\begin{abstract}
This study aims to determine the effectiveness of tax collection rate hotels and restaurants and their contribution to Local Revenue in Manokwari Regency in the period of 2014 - 2018. Methods of data collection in this study is the observation non-participant. The variable in this study is the ratio of the effectiveness and contribution to the Local Revenue. Data analysis in this study is quantitative analysis. According to data analysis, the average effective tax collection hotel and restaurants in the Manokwari Regency years 2014 - 2018 amounted to 91 percent, which is categorized effective, while the average contribution of tax revenue hotels and restaurants in the same period is 10,82 percent, which is grouped in a less good category.
\end{abstract}

Keywords: effectiveness, contribution, hotel and restaurant tax, local revenue

How to Cite: Koromath, J. P. (2019). Efektivitas Pemungutan Pajak Hotel dan Restoran di Kabupaten Manokwari Provinsi Papua Barat. JFRES: Journal of Fiscal and Regional Economy Studies, 2 (2), $1-6$.

\footnotetext{
Corresponding author :

E-mail: benikoromath@yahoo.co.id
} 


\section{PENDAHULUAN}

Berdasarkan Undang-Undang Nomor 23 Tahun 2004 tentang Pemerintah Daerah, bahwa otonomi daerah merupakan hak, wewenang dan kewajiban daerah otonomi untuk mengatur dan mengurus sendiri urusan pemerintah dan masyarakat setempat sesuai dengan ketentuan umum. Menurut Tadjoedien dan Murshed (2007), penyelenggaraan otonomi daerah dimulai secara efektif per tanggal 1 Januari 2001 menyebabkan pelaksanaan pemerintahan daerah banyak mengalami perubahan. Salah satu perubahan yang paling mendasar adalah adanya tuntutan akan akuntabilitas dan transparansi yang lebih besar dalam pengelolaan Anggaran Pendapatan dan Belanja Daerah (APBD). Otonomi daerah juga menuntut daerah untuk lebih mandiri dalam mengurus urusan permasalahan di berbagai bidang, termasuk kemampuan daerah dalam pelaksanaan pembangunan di daerahnya. Tingkat kesiapan fiskal daerah yang berbeda-beda merupakan salah satu kendala yang masih dihadapi pemerintah di dalam pelaksanaan otonomi daerah. Menurut Pepinsky (2008) dan Aragon (2009), dana yang diperoleh pemerintah daerah paling besar berasal dari pajak daerah, retribusi daerah, dan dana dari pemerintah pusat, yang digunakan untuk membiayai pembangunan. Tantangan yang dihadapi setiap daerah yang menerapkan otonomi daerah dan kebijakan desentralisasi adalah pemanfaatan peluang kewenangan yang diperoleh, serta tantangan untuk menjadi potensi daerah yang dimiliki guna mendukung kemampuan keuangan daerah sebagai modal pembiayaan dan penyelenggaraan pemerintah di daerah. Strategi untuk meningkatkan pendapatan asli daerah perlu dilakukan untuk menghadapi tantangan tersebut.

Sejalan dengan Undang-Undang Nomor 23 Tahun 2004 tentang Pemerintahan Daerah maka, Pemerintah Kabupaten Manokwari juga melaksanakan otonomi daerah. Menjadi salah satu daerah otonom di Provinsi Papua Barat yang memiliki potensi di berbagai sektor, Pemerintah Kabupaten Manokwari membutuhkan banyak dana untuk membiayai pembangunan daerah serta pelaksanaan pemerintahan. Untuk pembiayaan belanja daerah, pemerintah daerah menggunakan pendapatan yang berasal dari Pendapatan Asli Daerah dan pendapatan dari pemerintah pusat berupa transfer dana perimbangan (bagian dari bagi hasil pajak dan non pajak) dan Dana Alokasi Umum, Dana Alokasi Khusus, dan Dana Otonomi Khusus.

Pendapatan Asli Daerah merupakan pendapatan yang diperoleh daerah yang dipungut berdasarkan peraturan perundangundangan. Sumber Pendapatan Asli Daerah Kabupaten Manokwari yang merupakan potensi daerah terdiri dari Pajak Daerah, Retribusi Daerah, Laba Usaha, serta Lain-Lain Pendapatan Asli Daerah Yang Sah. Sumber Pendapatan Asli Daerah Kabupaten Manokwari disajikan pada Tabel 1.

Berdasarkan Tabel 1, dapat diketahui bahwa persentase potensi pendapatan terbesar yang diperoleh dari Pendapatan Asli Daerah selama 5 tahun terakhir berasal dari sektor pajak daerah. Beberapa jenis pajak daerah yang memiliki pengaruh terhadap Pendapatan Asli Daerah Kabupaten Manokwari adalah pajak hotel dan pajak restoran, pajak reklame, pajak penerangan jalan, pajak bea perolehan hak atas tanah dan bangunan, dan pajak bumi dan bangunan. Berikut ini sumber-sumber penerimaan pajak daerah yang dipungut oleh Pemerintah Daerah Kabupaten Manokwari selama 5 tahun terakhir.

Berdasarkan data pada Tabel 2, persentase potensi pendapatan terbesar yang diperoleh dari pajak daerah selama lima tahun terakhir adalah pajak bea perolehan hak atas tanah dan bangunan, pajak bumi dan bangunan serta pajak hotel dan pajak restoran. Pajak hotel dan restoran merupakan salah satu jenis pajak yang cukup menjanjikan di Kabupaten Manokwari mengingat Kabupaten Manokwari merupakan pusat ibu kota Provinsi Papua Barat dan pusat pemerintahan, pariwisata, perdagangan, dan perekonomian.

Target dan realisasi penerimaan pajak hotel dan restoran disajikan pada Tabel 3. Dapat dilihat bahwa realisasi penerimaan pajak hotel dan restoran pada tahun 2014, tahun 2015, dan tahun 2016 tidak mencapai target yang ditetapkan. Sedangkan pada tahun 2017 dan 2018 realisasi penerimaan pajak hotel dan restoran dapat melebihi target yang ditetapkan. Oleh sebab itu, sangatlah penting untuk meneliti efektivitas pemungutan pajak hotel dan restoran selama lima tahun terakhir. Pajak 
hotel dan restoran Kabupaten Manokwari harus diefektifkan pemungutannya sehingga dapat memberikan kontribusi yang maksimal terhadap pajak daerah yang pada akhirnya berpengaruh terhadap peningkatan pendapatan asli daerah Kabupaten Manokwari dalam pelaksanaan otonomi daerah.

Tabel 1. Komponen PAD Kabupaten Manokwari (Dalam Persentase)

\begin{tabular}{cccccc}
\hline Tahun & $\begin{array}{c}\text { Pajak Daerah } \\
(\%)\end{array}$ & $\begin{array}{c}\text { Retribusi } \\
\text { Daerah (\%) }\end{array}$ & $\begin{array}{c}\text { Laba Usaha } \\
(\%)\end{array}$ & $\begin{array}{c}\text { Lain-Lain } \\
\text { Pendapatan (\%) }\end{array}$ & $\begin{array}{c}\text { PAD } \\
(\%)\end{array}$ \\
\hline 2014 & 29,64 & 51,50 & 12,05 & 6,81 & 100,00 \\
2015 & 55,67 & 18,59 & 6,46 & 19,28 & 100,00 \\
2016 & 74,91 & 13,19 & 0,00 & 11,90 & 100,00 \\
2017 & 35,99 & 8,44 & 0,00 & 55,57 & 100,00 \\
2018 & 47,90 & 7,01 & 1,86 & 43,23 & 100,00 \\
\hline
\end{tabular}

Sumber : Laporan Realisasi Anggaran, 2019 (data diolah).

Tabel 2. Sumber Pajak Daerah yang dipungut oleh Pemerintah Kabupaten Manokwari (Dalam Persentase)

\begin{tabular}{cccccc}
\hline Jenis Pajak & $\mathbf{2 0 1 4}$ & $\mathbf{2 0 1 5}$ & $\mathbf{2 0 1 6}$ & $\begin{array}{c}\mathbf{2 0 1 7} \\
\mathbf{( \% )}\end{array}$ & $\begin{array}{c}\mathbf{2 0 1 8} \\
(\mathbf{\%})\end{array}$ \\
\hline Pajak Hotel dan Restoran & 15,11 & 15,16 & 21,08 & 19,96 & 23,58 \\
Pajak Hiburan & 0,70 & 0,74 & 0,76 & 1,50 & 2,51 \\
Pajak Reklame & 9,61 & 12,15 & 10,11 & 11,06 & 9,21 \\
Pajak Penerangan Jalan & 11,42 & 14,58 & 14,34 & 11,28 & 13,47 \\
Pajak Galian C & 1,31 & 4,73 & 1,98 & 16,64 & 12,28 \\
Pajak Parkir & 0,00 & 0,00 & 0,00 & 0,54 & 0.73 \\
Pajak Air Tanah & 0,00 & 0,00 & 0,00 & 0,00 & 0,03 \\
Pajak Mineral Bukan Logam & 0,54 & 0,00 & 0,00 & 0,00 & 0,00 \\
BPHTB & 47,38 & 37,39 & 31,74 & 25,79 & 25,38 \\
Pajak Bumi dan Bangunan & 13,93 & 15,24 & 19,98 & 13,22 & 12,82 \\
\hline
\end{tabular}

Sumber : Laporan Realisasi Anggaran, 2019 (data diolah).

Tabel 3. Target dan Realisasi Pajak Hotel dan Restoran Kabupaten Manokwari (dalam Ribuan Rupiah)

\begin{tabular}{|c|c|c|c|}
\hline \multirow[t]{2}{*}{ Tahun } & \multicolumn{2}{|c|}{ Pajak Hotel dan Restoran } & \multirow{2}{*}{$\begin{array}{c}\text { Persentase } \\
(\%)\end{array}$} \\
\hline & Target & Realisasi & \\
\hline 2014 & 3.700 .000 .000 & 3.149 .317 .797 & 85 \\
\hline 2015 & 5.250 .000 .000 & 2.550 .393 .534 & 49 \\
\hline 2016 & 5.450 .000 .000 & 4.315 .321 .027 & 79 \\
\hline 2017 & 7.359 .000 .000 & 8.413 .725 .645 & 114 \\
\hline 2018 & 9.891 .589 .008 & 10.264 .014 .452 & 104 \\
\hline
\end{tabular}

Sumber : Laporan Realisasi Anggaran, 2019 (data diolah).

\section{METODE PENELITIAN}

Penelitian ini dilakukan pada Badan Pendapatan Daerah Kabupaten Manokwari. Obyek dalam penelitian ini adalah efektivitas pemungutan pajak hotel dan restoran pada penerimaan PAD Kabupaten Manokwari Tahun Anggaran 2014 - 2018. Variabel yang digunakan dalam penelitian ini adalah efektivitas pemungutan pajak hotel dan restoran dan kontribusinya pada PAD Kabupaten Manokwari.

Efektivitas menggambarkan jangkauan akibat dan dampak dari keluaran program untuk mencapai tujuan program. Semakin besar kontribusi keluaran yang dihasilkan terhadap pencapaian tujuan dan sasaran yang ditentukan maka semakin efektif proses kerja suatu organisasi.
Efektivitas diukur dengan rasio efektivitas, yaitu perbandingan antara realisasi penerimaan pajak daerah dengan target yang ingin dicapai.

Rasio Efektivitas $=\frac{\text { Realisasi Penerimaan PHR }}{\text { Target Penerimaan PHR }} \times 100 \%$

Keterangan : PHR = Pajak Hotel dan Restoran Sumber : Mahsun, 2009.

Pemungutan pajak hotel dan restoran dikategorikan efektif apabila secara rasio yang dicapai minimal sebesar 1 atau $100 \%$. Semakin tinggi rasio efektivitas menggambarkan semakin efektif pula pemungutan pajak hotel dan restoran.

Kriteria efektivitas pemungutan pajak hotel dan restoran dapat dilihat pada Tabel 4 . 
Tabel 4. Kriteria Efektivitas Pemungutan Pajak Hotel dan Retoran

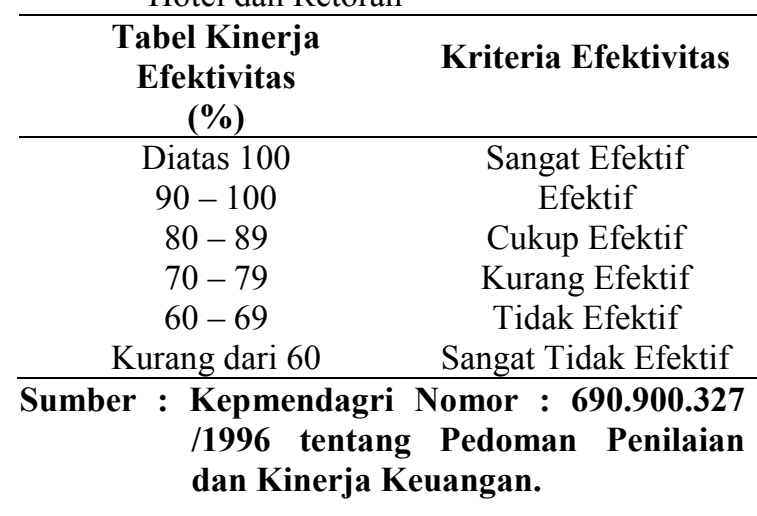

Besar kecilnya kontribusi pajak hotel dan restoran terhadap PAD dapat diukur dengan analisis kontribusi. Analisis kontribusi merupakan perbandingan antara penerimaan pajak hotel dan restoran pada satu tahun tertentu, dengan PAD pada tahun tertentu.

Analisis Kontribusi $=\frac{\text { PHR }}{\text { Penerimaan PAD }} \times 100 \%$

Keterangan :

PHR $=$ Pajak Hotel dan Restoran.

PAD $=$ Pendapatan Asli Daerah.

Semakin besar analisis kontribusi, maka semakin besar kontribusi yang dapat disumbangkan dari pemungutan pajak hotel dan restoran pada PAD Kabupaten Manokwari. Kontribusi dapat dikategorikan dalam kategori sangat baik apabila rasio menunjukkan angka
$>50$ persen. Kriteria kontribusi disajikan pada Tabel 5.

Tabel 5. Kriteria Kontribusi Pemungutan Pajak Hotel dan Retoran

\begin{tabular}{cc}
\hline Kontribusi (\%) & Kriteria Kontribusi \\
\hline$>50$ & Sangat Baik \\
$40,10-50,00$ & Baik \\
$30,10-40,00$ & Cukup Baik \\
$20,10-30,00$ & Sedang \\
$10,10-20,00$ & Kurang Baik \\
$<10$ & Sangat Kurang \\
\hline
\end{tabular}

Sumber : Tim Litbang Depdagri Fisipol UGM (Yuni, 2005).

\section{HASIL DAN PEMBAHASAN}

\section{Analisis Tingkat Efektivitas Pemungutan Pajak Hotel dan Restoran}

Tingkat efektivitas pemungutan pajak hotel dan restoran dapat diketahui dengan menggunakan rasio efektivitas, yaitu rasio yang menggambarkan kemampuan Pemerintah Daerah dalam merealisasikan pajak hotel dan restoran yang direncanakan dibandingkan dengan anggaran yang ditetapkan berdasarkan potensi riil daerah (Halim, 2007:234) yang dapat dihitung dengan membandingkan antara realisasi penerimaan pajak hotel dan restoran terhadap penerimaan PAD yang ditetapkan. Perhitungan efektivitas pemungutan pajak hotel dan restoran di Kabupaten Manokwari tahun anggaran 2014 - 2018 dapat dilihat pada Tabel 6.

Tabel 6. Perhitungan Efektivitas Pemungutan Pajak Hotel dan Restoran (dalam jutaan Rupiah)

\begin{tabular}{ccccc}
\hline Tahun & \multicolumn{2}{c}{ Pajak Hotel dan Restoran } & Rasio Efektivitas & Kriteria \\
\hline 2014 & 3.700 .000 .000 & 3.149 .317 .797 & 85 & Cukup efektif \\
2015 & 5.250 .000 .000 & 2.550 .393 .534 & 49 & Sangat tidak efektif \\
2016 & 5.450 .000 .000 & 4.315 .321 .027 & 79 & Kurang efektif \\
2017 & 7.359 .000 .000 & 8.413 .725 .645 & 114 & Sangat efektif \\
2018 & 9.891 .589 .008 & 10.264 .014 .452 & 104 & Sangat efektif \\
\hline Rata-Rata & $\mathbf{3 1 . 6 5 0 . 8 5 5 . 0 0 8}$ & $\mathbf{2 8 . 6 9 2 . 7 7 2 . 4 5 5}$ & $\mathbf{9 1}$ & efektif \\
\hline
\end{tabular}

Sumber : Data diolah, 2017.

Rata-rata rasio efektivitas Badan Pendapatan Daerah Kabupaten Manokwari tahun anggaran 2014 - 2018 adalah sebesar 91 persen. Sesuai dengan kriteria efektivitas pemungutan pajak hotel dan restoran pada tabel 4 di atas, rata-rata rasio efektivitas Badan Pendapatan Daerah Kabupaten Manokwari tahun anggaran 2014 2018 tergolong efektif, karena menunjukkan nilai rasio 91 persen. Nilai rasio efektivitas yang ditunjukkan lima tahun terakhir merupakan kinerja yang cukup baik karena perolehan pajak hotel dan restoran mulai menunjukkan peningkatan yang cukup baik pada tahun 2017 dan 2018. efektifitas yang telah ditunjukkan patut dipertahankan dan ditingkatkan lagi dengan cara Badan Pendapatan Daerah Kabupaten Manokwari lebih giat lagi dalam memungut pajak hotel dan restoran, serta mengevaluasi kembali apakah ada target yang telah ditetapkan sesuai dengan potensi yang sebenarnya.

\section{Analisis Tingkat Kontribusi Pajak Hotel dan Restoran pada PAD}


Analisis kontribusi merupakan analisis yang digunakan untuk mengetahui seberapa besar kontribusi yang dapat disumbangkan dari pemungutan pajak hotel dan restoran terhadap Pendapatan Asli Daerah (PAD). Hal ini dapat dilakukan dengan membandingkan antara realisasi penerimaan pajak hotel dan restoran terhadap Pendapatan Asli Daerah (Halim, 2004). Perhitungan kontribusi pajak hotel dan restoran terhadap Pendapatan Asli Daerah di Kabupaten Manokwari tahun anggaran 2014 2018 dapat dilihat pada Tabel 7.

Tabel 7. Kontribusi Pajak Hotel dan Restoran terhadap PAD Kabupaten Manokwari

\begin{tabular}{|c|c|c|c|c|}
\hline \multirow{2}{*}{ Tahun } & \multicolumn{2}{|c|}{ Analisis Kontribusi } & \multirow{2}{*}{$\begin{array}{c}\text { Analisis } \\
\text { Kontribusi (\%) } \\
\end{array}$} & \multirow{2}{*}{ Kriteria } \\
\hline & PHR & PAD & & \\
\hline 2014 & 3.149 .317 .797 & 10.016 .296 .743 & 31.44 & Cukup baik $(30,10-40,00)$ \\
\hline 2015 & 2.550.393.534 & 65.146 .675 .603 & 3.91 & Sangat kurang $(<10)$ \\
\hline 2016 & 4.315.321.027 & 66.111 .797 .828 & 6.53 & Sangat kurang $(<10)$ \\
\hline 2017 & 8.413 .725 .645 & 54.373 .489 .489 & 15.47 & Kurang baik $(10,10-20,00)$ \\
\hline 2018 & 10.264 .014 .452 & 58.658 .566 .131 & 17.50 & Kurang baik $(10,10-20,00)$ \\
\hline Rata-Rata & 28.692.772.455 & 265.204.975.707 & 10.82 & Kurang baik $(10,10-20,00)$ \\
\hline
\end{tabular}

Sumber : Laporan Realisasi Anggaran, 2019 (data diolah).

Pencapaian tingkat kontribusi pajak hotel dan restoran pada Pendapatan Asli Daerah di Kabupaten Manokwari tahun anggaran 2014 2018 selalu mengalami peningkatan namun tidak terlalu signifikan. Jika dilihat secara keseluruhan, rata-rata tingkat kontribusi pajak hotel dan restoran pada Pendapatan Asli Daerah di Kabupaten Manokwari selama lima tahun terakhir masuk dalam kategori kurang baik. Hal ini berarti bahwa Kabupaten Manokwari belum optimal mengintensifkan dan mengekstensifkan potensi pajak hotel dan restoran sehingga perlu mengefektifkan pemungutan pajak hotel dan restoran sesuai potensi riil yang ada, sehingga kontribusinya dapat meningkatkan pada Pendapatan Asli Daerah dalam rangka melaksanakan otonomi daerah.

\section{KESIMPULAN DAN SARAN}

Rata-rata tingkat efektifitas pemungutan pajak hotel dan restoran di Kabupaten Manokwari dari tahun 2014 - 2018 yang diukur dengan rasio efektifitas adalah sebesar 91 persen dan tergolong dalam kategori efektif. Tingkat kontribusi pemungutan pajak hotel dan restoran pada Pendapatan Asli Daerah pada tahun 2014 digolongkan dalam kategori cukup baik dengan tingkat kontribusi sebesar 31,44 persen. Pada tahun 2015 - 2016 digolongkan dalam kategori sangat kurang dengan tingkat kontribusi sebesar 3,91 persen dan 6,53 persen. Selanjutnya pada tahun 2017 - 2018 digolongkan dalam kategori kurang baik dengan tingkat kontribusi 15,47 persen dan 17,50 persen.

Saran yang dapat diberikan berdasarkan kesimpulan dari penelitian ini adalah perlu kerja keras dari Badan Pendapatan Daerah dalam memaksimalkan pemungutan pajak hotel dan restoran pada obyek pajak yang ada di Kabupaten Manokwari. Selain itu Badan Pendapatan Daerah perlu mengevaluasi kembali target yang ditetapkan apakah sudah sesuai dengan potensi riil. Rata-rata tingkat kontribusi pemungutan pajak hotel dan restoran terhadap Pendapatan Asli Daerah Kabupaten Manokwari digolongkan dalam kategori kurang baik, sehingga kondisi ini harus mendapat perhatian serius Badan Pendapatan Daerah dengan melakukan langkah-langkah nyata seperti ekstensifikasi dan intensifikasi pemungutan pajak hotel dan restoran untuk meningkatkan kontribusinya terhadap Pendapatan Asli Daerah Kabupaten Manokwari dalam rangka mewujudkan otonomi daerah.

\section{DAFTAR PUSTAKA}

Aragon, Fernando. 2009. The Flypaper Effect Revisited. Economic Organization And Public Policy Research. Sticerd London Of School Of Economic.4.

Halim, Abdul. 2007. Akuntansi Sektor Publik. Edisi Revisi. Jakarta : Salemba Empat.

Keputusan Menteri Dalam Negeri Nomor : 690.900-327 Tahun 1996 Tentang Pedoman Penilaian dan Kinerja Keuangan.

Mahsun, Mohamad. 2009. Akuntansi Sektor Publik. BPFE-Yogyakarta.

Tadjoedien, M. And Murshed, S. 2007. Socioeconomic Determinants of Everyday Violence In Indonesian : An Empirical Investigation Of Javanese 
Districts, 1994-2003. Journal Of Peace Researc, 44 (6) : 689-709.

Pepinsky, Thomas B. 2008. Institusional, Economic Recovery, And Macroecomic Performance In Indonesian. Cornell Univercity. Journal of Center for Strategic And International Studies.
Undang-Undang Nomor 23 Tahun 2004 Tentang Pemerintah Daerah.

Yuni, Mariana. 2005, Analisis Kontribusi Pajak Parkir pada Dinas Pendapatan Daerah Terhadap Pendapatan Asli Daerah Kota Bandung. Skripsi Bandung : Universitas Pendidikan Indonesia. 